\title{
Effect of Educational Program Regarding Perioperative Hypothermia on Nurses` Performance and Abdominal Surgery Patients`Outcomes
}

\author{
Naglaa Fathy Mahmoud ${ }^{1}$, Amal Said Taha ${ }^{2}$, Safaa Mohammed Hamed ${ }^{3}$ \\ (1) Teacher at Secondary Technical Nursing school in Albagour-Menofyia, (2)Assistant Professor \\ of Medical Surgical Nursing. Faculty of Nursing.Benha university and Lecturer of Medical Surgical \\ Nursing. Faculty of Nursing. Benha university
}

\begin{abstract}
Back ground: Perioperative hypothermia is a significant problem for surgical patients globally, and is associated with a range of adverse effects, including inflammation, prolonged surgical wound healing, increased wound infection rates, and prolonged hospital stay. Aim of the study: To evaluate the effect of educational program regarding perioperative hypothermia on nurses performance and abdominal surgery patients` outcomes. A quasi experimental research design was utilized to conduct the aim of the study. Sampling: A convenient sample of all available nurses (85 nurses) who are working in operating room and general surgical ward were included in the study. A fifty purposive sample of patients who were admitted to general surgical ward and operating room up to six months included in the study. Setting: The current study was conducted in operating room and general surgical ward (male \& female) at Benha University hospital. Tools for data collection: Data were obtained through three tools; Self-administered questionnaire for nurses, Nurses practice observational checklist and patients`outcomes tool. Result: The study showed that a highly statistical significant improvement in the total mean knowledge and practice scores of studied nurses immediately post and after one month of program implementation as compared to preprogram implementation. Also, there was a highly statistically significant improvement in nurses` total practice and wound assessment score post program implementation with statistical significant between nurses` total practice and length of hospital stay immediately post of program implementation. Conclusion; there was positive correlation between nurses` total knowledge and practices regard perioperative hypothermia through program phases, which indicated that improved patients' outcome. The study recommended that, there is needed for replication of the current study on larger probability sample is recommended to achieve generalization of the results. Also, there is needed to duplicate the study to determine the effect of educational program on postoperative patient outcome.
\end{abstract}

Keywords: Perioperative hypothermia, Educational Program, Nurses 'Performance, Patients' outcome

\section{Introduction}

Perioperative Hypothermia ( $\mathrm{PH})$, defined as the body's core temperature below $36^{\circ} \mathrm{C}$, is common in patients undergoing surgery. Starting one hour before the operation and continuing into the postoperative period. The incidence varies between $11 \%$ and $90 \%$ depending on the type of surgery conducted and anesthesia administered. The risk increases in patients with risk score of an age of $\geq 60$ years, a low body mass index, those who receive a combination of general and regional anesthesia; and those who undergo moderate 
or major surgery, also has been shown to alter intraoperative drug effects, increase bleeding and delay the recovery time, increase cardiac side effects, and increase infection rates (Urfalioglu et al., 2021).

Perioperative hypothermia may cause physical damage and discomfort, increases postoperative complications, patients can have significant consequences during surgery and in the immediate postoperative period. It occurs when the body is unable to produce enough heat to counter the heat that it is losing. Hypothermia can develop at any stage during the surgical pathway: pre-operatively, intra-operatively or post-operatively that has three main reasons: a reduction in heat production, an increase in loss of heat or dysfunction of the thermoregulatory mechanisms (Matilda et al., 2020). Hypothermia occurs in the majority of patients undergoing major abdominal surgery and contributes significantly to increase patient care costs, increases thermal discomfort and the duration of hospitalization up to $20 \%$ (Landry et al., 2019).

Management of hypothermia during the perioperative period needs to remain an important aspect of perioperative nursing. This is a key factor in maintaining patient safety, achieving positive surgical outcomes and patient satisfaction. The American Society of PeriAnesthesia Nurses (ASPAN) has developed an evidence-based guideline for the prevention of perioperative hypothermia in surgical patients that can be implemented at nominal additional time or cost. It consists of assessments and interventions to manage perioperative hypothermia including passive and active warming devices and prewarming methods throughout the preoperative, intraoperative, and postoperative stages (Kang\& Park, 2020).

\section{Significance of the study}

Patients who had undergone major abdominal surgeries were prone to the development of intra operative hypothermia than other surgeries, remains a threat to all surgical patients undergoing general anesthesia. The reported incidence of deaths due to hypothermia number around 1,500 annually in the United States and around 125 annually in Poland (Darocha, 2019).

The reported incidence of hypothermia in the perioperative period is between $25 \%$ and 80\% Today, as a result of Unintended Perioperative Hypothermia, the effects of the anesthetic agents and neuromuscular blockers are prolonged, the need for blood transfusion increases depending on the increased blood loss, cardiac complications may develop, the post anesthetic recovery delays, the risk of surgical wound infection increases, the duration of the hospitalization prolongs, and finally the cost increases (Şenkal \& Kara, 2020).

\section{Aim of the study:}

The aim of this study was to evaluate the effect of educational program regarding perioperative hypothermia on nurses` performance and abdominal surgery patients` outcomes.

This study will be achieved through the following:

1. Assess the nurses' level of knowledge regarding perioperative hypothermia

2. Assess the nurses' level of practice regarding perioperative hypothermia.

3. Assess patients' outcomes

\section{Research Hypothesis}

H1: The post means knowledge scores of nurses will have higher than their pretest knowledge mean scores 


\section{Effect of Educational Program Regarding Perioperative Hypothermia on Nurses` \\ Performance and Abdominal Surgery Patients` Outcomes}

H2: The post means practice scores of nurses will have higher than their pre practice mean scores.

H3: Patients who are exposed to educational program will have less hospital stay than those were not.

H4: Wound status score will improved among patients who are exposed to the educational program than those who are not

\section{Subjects and methods}

\section{Research design:}

A quasi experimental research design was utilized to meet the aim of this study.

\section{Setting:}

The study was conducted in the operating room and surgical ward at Benha University Hospital

\section{Subjects:}

For nurses: A convenient sample of 85 nurses, working in previously mentioned setting, was recruited to this study.

For patients: A purposive sample of 50 adult patients were admitted at the above mentioned setting up to six months, was included in this study from both sexes( male \& female ), who undergoing abdominal surgery and willing to participate in the study.

Subjects included in the study were selected according to the following criteria:

\section{Inclusion criteria:}

Adult male and female patients who had undergoing abdominal surgery.

\section{Tool for data collection:}

\section{Tools for nurses:}

The data was collected through the following three tools:
Tool I: Self-administered questionnaire for nurses (Appendix I) This tool was developed by the researcher. It was include three parts as the following:

Part I: Socio demographic data: It was concerned with socio-demographic characteristics of nurses. It included 8 close ended questions about name, sex, age, marital status, level of education, year of experience in operating room, year of experience in surgical wards, and training courses about perioperative hypothermia .

Part II: Nurses` knowledge (pre/ post test): It was concerned with the assessment of nurses' knowledge regarding perioperative hypothermia. It consists of 19 multiple choice questions. It included 3 items and disturbed as the following: general knowledge about hypothermia which was included (10 questions), knowledge about sign \& symptoms hypothermia, which was included (4 questions), and knowledge about nursing management of perioperative hypothermia which was included (5 questions). Total questions were 19 questions.

Scoring system: Knowledge obtained from nurses were scored and calculated according answers, it was evaluated using model key answer sheet prepared by the researcher. Each question was ranged from 0-1 score, whereas, the right answer were given one scores, and the wrong answer were given zero score, with total score was (19) scores (100\%). Theses scores were summed- up and converted into a percent score. It was categorized as follow:

- Score $\geq \mathbf{7 5 \%}$ was considered satisfactory level of knowledge.

- Score $<\mathbf{7 5 \%}$ was considered un satisfactory level of knowledge

Tool II: observational check list assessment (pre/ posttest): This tool developed by the researcher after reviewing related literature 
(AORN, 2018), to assess the nurses practice regard nursing care of perioperative hypothermia during (pre- intraoperative care - post operative care). The observational checklist divided into 3 parts. Part I of pre-operative observational check list composed of (8 steps). Part II of intraoperative observational check list composed of (7 steps). And the part III of post- operative observational check list composed of (5 steps). Total steps were 20 steps.

\section{Scoring system:}

2 score $=$ Done completely,

1 score $=$ Done incompletely

Zero $=$ Not done

The total level of nurses` practice score was categorized as follows:

Score $\geq \mathbf{8 0} \%$ was considered competent level of practice.

Score $<\mathbf{8 0 \%}$ was considered in competent level of practice.

\section{Tool (III): Clinical outcome assessment :} Structure interviewing questionnaire:

It was developed by the researcher based on literature review. It was included four parts as the following:

Part I: Patient's socio demographic characteristics: It included (Age, gender, occupation, level of education, place of residence, marital status)

Part II: Patient's medical history: It included 9 close ended questions as presence of chronic disease, previous surgery and present medical history, patient ' chief complaints, diagnosis, type of surgery, drug ordered, assessment of patient vital signs as temperature, pulse, blood pressure and respiration.
Part III: Patient wound assessment tool: This tool was adopted from BATES-JENSE, (2019), that provides a numerical scores, used to determines the total score by adding together the 12-item scores, (Size, Depth, Edges, Undermining, Necrotic tissue type, Necrotic tissue amount, Exudate type, Exudate amount, Skin color, Edema, Granulation, Epithelialization). Each item of Bates-Jensen Wound Assessment Tool (BWAT) was assessed and scores were measured on a five-point Likert scale, where one indicates the best condition of the wound and five, the worst condition. The total score is obtained as the sum of all the items.

\section{Scoring system:}

The scoring system adopted from BATESJENSE, (2019) was categorized as follow:

- Satisfactory healing ( 0 -10)

-disturbance of healing (11-20)

-minor wound infection (21-30)

-moderate wound infection (31-40)

- Severe wound infection (> 40)

Part VI: Length of hospital stay: This tool was adopted from (Paul, 2019). And used to assess the average number of days that patients was spending in surgical ward after the operation

\section{Content validity:}

Validity of tools was done by a group of experts to check the relevancy, clarity, comprehensiveness, and applicability of the questions. According to their opinion, minor modifications were done and the final forms were developed. Face and content validation of the studied tools were done according to opinions of the 7 experts in related fields. Jury experts involved three professors and two assistant professor of medical surgical nursing department in the faculty of nursing, Benha 


\section{Effect of Educational Program Regarding Perioperative Hypothermia on Nurses` Performance and Abdominal Surgery Patients`Outcomes}

University. Also there was assistant professor of anesthesia and professor of surgery in faculty of medicine at Benha University.

\section{Reliability:}

Reliability of the developed tools was done statistically through Chronbach`s Alpha test to measure the internal consistency of the tool. that was 0.687 for nurse`s knowledge questionnaire and 0.519 for nurse`s practice observational check list.

\section{Ethical considerations:}

Written approval was obtained from the research ethical committee of faculty of nursing, also an official permission was obtained from hospital administrators to conduct the study. Each nurse and patient was informed about the purpose, nature and significance of the study, the research assured maintaining anonymity and confidentiality of objective data, every participant has the right to withdraw from the study at any time.Informed consent from the nurses to apply this study was secured. Subjects were assured that this data was not be reused in another research without permission. Patients were assured that their participation is voluntary and they have the right to withdraw from the study at any time without any penalty

\section{Pilot study:}

A pilot study was carried out on $10 \%$ of the study subjects ( 8 nurses and 5 patients) in order to test the clarity, applicability, feasibility, relevance of the data collection, and to identify any possible obstacles that may hinder the data collection. Nurses and patients involved in the pilot study were included in the total study subjects as no modifications were done.

\section{Field work:}

The study was conducted over period of 6 months started from June 2020 to the end of November 2020. Data was collected 4 days (Saturday, Sunday, Monday, and Thursday) per week at morning and afternoon shifts in the surgical operating room and surgical wards at Benha University.

\section{-The data collection in the four phases:}

\section{Phase I: "Assessment phase":}

\section{For nurses:}

After the study program has been approved, an official permission was taken from the director of Benha university hospital after explanation of the purpose of the study. Once the researcher has gained the approval; the researcher visited the setting and met nurses and patients to explain the purpose and nature of the study in order to gain their cooperation before data collection.

Observational checklist (Tool II) was filled by the researcher and it took 45 minutes for each nurse to fill it. The nurse`s practice was assessed using the continuous observation method throughout each procedure.

The nurse`s practice was assessed using the continuous observation method throughout each procedure. Each observation sheet was filled immediately while observing the nurses when performing each procedure. "Structured interviewing questionnaire tool" to collect the required data. The pre-test questionnaire was administrated to assess the nurses` knowledge individually (Tool I). The questions were in simple Arabic language and the answers were recorded immediately. It took about 15-20 minutes for each nurse. 


\section{For patients:}

Researcher collected patients` socio demographic data from patients` by using tool (III), which include Age, gender, occupation, level of education, place of residence, marital status, presence of chronic disease, previous surgery and present medical history, patient chief complaints, diagnosis, type of surgery, drug ordered. And measure vital signs (temperature, pulse, blood pressure, respiration).

Researcher used tool III to assess wound status scores according to Bates- Jensen wound assessment tool items to detect the severity of wound status. And also assessed the average number of days that patients was spending in surgical ward after the operation

\section{Phase II: "Planning phase":}

The nurses' learning needs were identified and classified into knowledge and practice. Detected needs, requirement and practice deficiencies were translated to aim and objectives of educational program. Educational Program was designed in Arabic language by the researcher based on nurses` need after reviewing the most recent literature and provided in a form of a booklet. Booklet was color printed and was supplemented by photos for more illustration and to help the nurses to understand the content.

\section{Phase III" Implementation phase"}

\section{For nurses:}

-The nurses were divided into small groups (3-5 nurses) according to work situations and the program was provided on small sessions (2030minutes) the number of sessions was varied according to their level of understanding

- The content of educational program was introduced in four educational and practical sessions.
-These sessions were divided into; three sessions for theoretical part and one sessions for the practical part.

- Booklet was designed and given to each nurse included a teaching module to grasp their attention and motivate them.

- Explanation of the educational program by using discussion, demonstration and redemonstration.

\section{For patients:}

Researcher collected the demographic data and medical history from patients at three time pre, immediately post, after one month of educational program by using tool III (patients` outcome tool).

The researcher attendance with the patients in dressing room to assess wound status during dressing time according to Bates- Jensen wound assessment tool items at three times pre, immediately post, after one month of program.

Researchers assessed the average number of days that patients was spending in surgical ward after the operation.

\section{Phase V "Evaluation phase":}

- Each nurse in the study was evaluated immediately post and after one month of program implementation and data was collected using (tool I).

- Nurses practice was evaluated immediately post and after one month of program implementation by the researcher to fill out nurses' practice assessment (tool II).

- Evaluation of studied patients was done for three times during the study pre, immediately after, and after one month of educational program implementation by using (tool III). 


\section{Effect of Educational Program Regarding Perioperative Hypothermia on Nurses` Performance and Abdominal Surgery Patients` Outcomes}

\section{Results}

Table I demonstrate frequency and percentage distribution of studied nurses socio demographic characteristics, it shows about slightly less than half $(48.2 \%)$ of studies nurses were less than 30 years old, concerning gender about three quarter $(74.1 \%)$ of them was female ,the majority $(80.0 \%)$ of them were married. A additionally, more than half of them $(58.8 \%)$ graduate from clinical nursing institute. And the majority $(83.5 \%)$ of them had from 1 to less than 5 years of experience additionally. All studied nurses (100\%) had not attended previous training course about perioperative hypothermia.

Table 2 reveals that, heat loss occurs through the indirect contact with the patient's cold body, about three quarters $(74.1 \%)$ of studied nurses had incorrect answer during preprogram implementation, while the majority $(96.5 \%)$ of them had correct answer during immediately post program implementation and more than three quarters (87.1\%) of them had correct answer after one month of program implementation. Regarding mechanism of the patient's body heat loss slightly less than half (45.9\%) of studied nurses had incorrect answer preprogram implementation but the all of studied nurses (100\%) had correct answer immediately post program implementation, while, and the majority of them (92.2\%) had correct answer after one month of program implementation. Also, this table clarifies there were highly statistical significant differences $(\mathrm{P} \leq 0.000)$ regarding the all items of nurses' knowledge about perioperative hypothermia among immediately post and after one month of program implementation.
Table 3 reveals that all (100\%) of studied nurses don 't assess patients' sign and symptoms of hypothermia at preprogram implementation, while more than two thirds $(71,8 \%)$ of them had completely done immediately post of program implementation, but about two thirds $(62.4 \%)$ of studied nurses had completely done after one month of program implementation. On the other side, regarding maintain patients` body temperature at $36^{\circ} \mathrm{C}$, slightly more than half $(56.5 \%)$ of studied nurses had incomplete done during preprogram implementation while less than three quarters $(71.8 \%)$ of them had complete done immediately post of program implementation, and more than two thirds (69.4\%)of them had completely done after one month of program implementation. Additionally, there were statistical significant differences $(\mathrm{P}<0.000)$ in nurses practice regarding all items of intraoperative practice about hypothermia among immediately post and after one month of program implementation.

Table 4 Describes that, there were a highly statistically significant differences with positive correlation between the studied nurses' total knowledge and practices level at preprogram implementation $(p \leq 0.000)$. Moreover, there was a statistically significant difference with positive correlation between total knowledge and practice level immediately post and after one month of program implementation

Table 5 Demonstrates the percentage distribution of studied patients according to their demographic characteristics. It shows about more than half $(54.0 \%)$ of studied patients, their age was 40 years or over, with mean age $40.40 \pm 12.196$. Near three quarters of them $(76.0 \%)$ Were female and the majority of them $(80.0 \%)$ were married, slightly less than half $(46.0 \%)$ of them had university education, and slightly less than half $(42.0 \%)$ of them 
were work and about two thirds (64.0\%) of them were living in urban

Table 6 Illustrates that, regarding BatesJensen wound assessment score of studied patients, the lowest percentage (14\%) of studied patients has disturbance of healing preprogram implementation, and lowest percentages $(8 \%, 6 \%)$ of them respectively have disturbance of healing immediately post and after one month of program implementation. On other side, about the minority $(10 \%)$ of studied patients preprograms implementation, and lowest percentages $(6 \%, 6 \%)$ respectively immediately post and after one month of program implementation have wound infection with no statistically significant differences.

Table 7: Clarifies that there was positive correlation between studied nurses total practice level and wound assessment score through program phases, with a highly statistical significant immediately post of program implementation. 
Table 1: Frequency and percentage distribution of studied nurses`demographic characteristics $(\mathbf{n}=\mathbf{8 5})$.

\begin{tabular}{|c|c|c|}
\hline Personal characteristics & NO & $\%$ \\
\hline \multicolumn{3}{|l|}{ Age in year } \\
\hline$<30$ & 41 & 48.2 \\
\hline $30-<35$ & 13 & 15.3 \\
\hline $35+$ & 31 & 36,5 \\
\hline Min - Max & \multicolumn{2}{|c|}{$18-49$} \\
\hline Range & \multicolumn{2}{|c|}{31} \\
\hline Mean \pm SD & \multicolumn{2}{|c|}{$31.40 \pm 8.911$} \\
\hline \multicolumn{3}{|l|}{ Gender } \\
\hline Female & 63 & 74.1 \\
\hline Male & 22 & 25.9 \\
\hline \multicolumn{3}{|l|}{ Marital status } \\
\hline Not married & 17 & 20.0 \\
\hline Married & 68 & 80.0 \\
\hline \multicolumn{3}{|l|}{ Qualifications } \\
\hline Secondary nursing education & 17 & 20.0 \\
\hline Clinical Nursing Institute & 50 & 58.8 \\
\hline Bachelor degree in Nursing & 16 & 18.8 \\
\hline Postgraduate Diploma & 2 & 2.4 \\
\hline \multicolumn{3}{|c|}{ Years of experience in the operating room and surgical department } \\
\hline $1<5$ & 71 & 83.5 \\
\hline $5-<10$ & 6 & 7.1 \\
\hline $10+$ & 8 & 9.4 \\
\hline Mean \pm SD & \multicolumn{2}{|c|}{$3.56 \pm 7.505$} \\
\hline \multicolumn{3}{|c|}{ Previous training courses regarding perioperative hypothermia $(\mathbf{n}=\mathbf{8 5})$} \\
\hline No & & \\
\hline
\end{tabular}


Table (2): Percentage distribution of studied nurses` knowledge regarding perioperative hypothermia through program phases $(n=85)$.

\begin{tabular}{|c|c|c|c|c|c|c|c|c|c|c|}
\hline \multirow{2}{*}{$\begin{array}{l}\text { Knowledge } \\
\text { items }\end{array}$} & \multicolumn{2}{|c|}{ Pre } & \multicolumn{2}{|c|}{$\begin{array}{l}\text { Immediately } \\
\text { post }\end{array}$} & \multicolumn{2}{|c|}{$\begin{array}{l}\text { After one } \\
\text { month }\end{array}$} & \multirow[t]{2}{*}{$\mathbf{X}^{2} \mathbf{1}$} & \multirow{2}{*}{ P-value } & \multirow{2}{*}{$X^{2} 2$} & \multirow{2}{*}{$\begin{array}{c}\text { P- } \\
\text { value }\end{array}$} \\
\hline & No & $\%$ & No & $\%$ & No & $\%$ & & & & \\
\hline \multicolumn{11}{|c|}{ Definition of hypothermia } \\
\hline Correct & 62 & 72,9 & 85 & 100.0 & 79 & 92.9 & \multirow[b]{2}{*}{20.13} & \multirow[b]{2}{*}{$.000 * *$} & \multirow[b]{2}{*}{12.01} & \multirow[b]{2}{*}{ 0.001* } \\
\hline In correct & 23 & 27.0 & $\mathbf{0}$ & $\mathbf{0 . 0}$ & 6 & 7.1 & & & & \\
\hline \multicolumn{11}{|c|}{ Stages of perioperative hypothermia } \\
\hline Correct & 34 & 40.0 & 84 & 98.8 & 83 & 97.6 & \multirow[b]{2}{*}{96.26} & \multirow[b]{2}{*}{$.000 * *$} & \multirow[b]{2}{*}{65.82} & \multirow[b]{2}{*}{$.000 * *$} \\
\hline Incorrect & 51 & 60.0 & 1 & 1.2 & 2 & 2.4 & & & & \\
\hline \multicolumn{11}{|c|}{ Indirect heat loss } \\
\hline Correct & 22 & 25.9 & 82 & 96.5 & 74 & 87.1 & \multirow[b]{2}{*}{89.16} & \multirow[b]{2}{*}{$.000 * *$} & \multirow[b]{2}{*}{64.70} & \multirow[b]{2}{*}{$.000 * *$} \\
\hline Incorrect & 63 & 74.1 & 3 & 3.5 & 11 & 12.9 & & & & \\
\hline \multicolumn{11}{|c|}{ Causes of hypothermia } \\
\hline Correct & 50 & 58.8 & 84 & 98.8 & 78 & 91.8 & \multirow[b]{2}{*}{40.73} & \multirow[b]{2}{*}{$.000 * *$} & \multirow[b]{2}{*}{24.79} & \multirow[b]{2}{*}{$.000 * *$} \\
\hline Incorrect & 35 & 41.2 & 1 & 1.2 & 7 & 8.2 & & & & \\
\hline Mechanism of $t$ & patie I & s bod & y heat & & & & & & & \\
\hline Correct & 46 & 54.1 & 85 & 100.0 & 79 & 92.9 & & & & \\
\hline Incorrect & 39 & 45.9 & $\mathbf{0}$ & 0.0 & 6 & 7.1 & 50.61 & $.000 * *$ & 32.91 & $.000 * *$ \\
\hline Definition of hy & herm & & & & & & & & & \\
\hline Correct & 33 & 38.8 & 71 & 83.5 & 71 & 83.5 & & & & \\
\hline Incorrect & 52 & 61.2 & 14 & 16.5 & 14 & 16.5 & 35.76 & $.000 * *$ & 35.76 & $.000 * *$ \\
\hline Direct heat los & & & & & & & & & & \\
\hline Correct & 43 & 50.6 & 63 & 74.1 & 60 & 70.6 & & & & \\
\hline Incorrect & 42 & 49.4 & 22 & 25.9 & 25 & 29.4 & 10.02 & .002 & 7.11 & .008 \\
\hline Definition of se & hypo & ermi & & & & & & & & \\
\hline Correct & 27 & 31.8 & 46 & 54.1 & 38 & 44.7 & 8.667 & .003 & 3.01 & .083 \\
\hline Incorrect & 58 & 68.2 & 39 & 45.9 & 47 & 55.3 & & & & \\
\hline heat loss that o & es to t & e pati & ent thr & igh the & irwas & & & & & \\
\hline Correct & 33 & 38.8 & 81 & 95.3 & 81 & 95.3 & & & & \\
\hline Incorrect & 52 & 61.2 & 4 & 4.7 & 4 & 4.7 & 61.35 & $.000 * *$ & 61.35 & $.000 * *$ \\
\hline Definition of sl & hyp & herm & & & & & & & & \\
\hline Correct & 43 & 50.6 & 81 & 95.3 & 78 & 91.8 & & & & \\
\hline Incorrect & 42 & 49.4 & 4 & 4.7 & 7 & 8.2 & 43.03 & $.000 * *$ & 35.12 & $.000 * *$ \\
\hline
\end{tabular}

${ }^{\mathrm{X} 2} 1$ between pre and post program ${ }^{\mathrm{X} 2} 2$ between pre and after one month progra

*A statistical significant differences $(\mathrm{P} \leq 0.05) * *$ A highly statistically significant differences $(\mathrm{P} \leq 0.001)$ 
Table (3): Frequency and percentage distribution of studied nurses` practice regarding their intraoperative care about hypothermia (pre, immediately post, and after one month of program implementation

\begin{tabular}{|c|c|c|c|c|c|c|c|c|c|c|}
\hline \multirow{2}{*}{$\begin{array}{c}\text { Practice } \\
\text { items }\end{array}$} & \multicolumn{2}{|c|}{ pre } & \multicolumn{2}{|c|}{$\begin{array}{c}\text { Immediately } \\
\text { post }\end{array}$} & \multicolumn{2}{|c|}{$\begin{array}{l}\text { After one } \\
\text { month }\end{array}$} & \multirow[t]{2}{*}{$X^{2} 1$} & \multirow[t]{2}{*}{ P-value } & \multirow[t]{2}{*}{$\mathrm{X}^{2} 2$} & \multirow[t]{2}{*}{ P-value } \\
\hline & No & $\%$ & No & $\%$ & No & $\%$ & & & & \\
\hline \multicolumn{11}{|c|}{ Measure patient` temperature } \\
\hline $\begin{array}{l}\text { Done } \\
\text { completely }\end{array}$ & $\mathbf{0}$ & $\mathbf{0 . 0}$ & 61 & 71.8 & 55 & 64.7 & \multirow[t]{3}{*}{106.0} & \multirow[t]{3}{*}{$0.000 * *$} & \multirow[t]{3}{*}{89.78} & \multirow[t]{3}{*}{$0.000 * *$} \\
\hline $\begin{array}{l}\text { Done } \\
\text { Incompletely }\end{array}$ & 48 & 56.5 & 24 & 28.2 & 27 & 31.8 & & & & \\
\hline Not done & 37 & 43.5 & $\mathbf{0}$ & $\mathbf{0 . 0}$ & 3 & 3.5 & & & & \\
\hline \multicolumn{11}{|c|}{ Assessment thermal comfort level } \\
\hline $\begin{array}{l}\text { Done } \\
\text { completely }\end{array}$ & $\mathbf{0}$ & $\mathbf{0 . 0}$ & $\mathbf{0}$ & $\mathbf{0 . 0}$ & 53 & 62.4 & \multirow[t]{3}{*}{95.13} & \multirow[t]{3}{*}{$0.000 * *$} & \multirow[t]{3}{*}{88.03} & \multirow[t]{3}{*}{$0.000 * *$} \\
\hline $\begin{array}{l}\text { Done } \\
\text { Incompletely }\end{array}$ & $\mathbf{0}$ & $\mathbf{0 . 0}$ & 61 & 71.8 & 5 & 5.9 & & & & \\
\hline Not done & 85 & 100.0 & 24 & 28.2 & 27 & 31.8 & & & & \\
\hline \multicolumn{11}{|c|}{ Maintain the ambient operating room temperature } \\
\hline $\begin{array}{l}\text { Done } \\
\text { completely }\end{array}$ & $\mathbf{0}$ & $\mathbf{0 . 0}$ & $\mathbf{0}$ & $\mathbf{0 . 0}$ & 56 & 65.9 & \multirow[t]{3}{*}{95.13} & \multirow[t]{3}{*}{$0.000 * *$} & \multirow[t]{3}{*}{90.36} & \multirow[t]{3}{*}{$0.000 * *$} \\
\hline $\begin{array}{l}\text { Done } \\
\text { Incompletely }\end{array}$ & $\mathbf{0}$ & $\mathbf{0 . 0}$ & 61 & 71.8 & 3 & 3.5 & & & & \\
\hline Not done & 85 & $\mathbf{1 0 0 . 0}$ & 24 & 28.2 & 26 & 30.6 & & & & \\
\hline \multicolumn{11}{|c|}{ Maintain body temperature at $36^{\circ} \mathrm{C}$} \\
\hline $\begin{array}{l}\text { Done } \\
\text { completely }\end{array}$ & $\mathbf{0}$ & $\mathbf{0 . 0}$ & 61 & 71.8 & 59 & 69.4 & \multirow[t]{3}{*}{106.0} & \multirow[t]{3}{*}{$0.000 * *$} & \multirow[t]{3}{*}{100.35} & \multirow[t]{3}{*}{$0.000 * *$} \\
\hline $\begin{array}{l}\text { Done } \\
\text { Incompletely }\end{array}$ & 48 & 56.5 & 24 & 28.2 & 25 & 29.4 & & & & \\
\hline Not done & 37 & 43.5 & $\mathbf{0}$ & $\mathbf{0 . 0}$ & 1 & 1.2 & & & & \\
\hline \multicolumn{11}{|c|}{ Assess patient sign\& symptoms of hypothermia } \\
\hline $\begin{array}{l}\text { Done } \\
\text { completely }\end{array}$ & $\mathbf{0}$ & $\mathbf{0 . 0}$ & 61 & 71.8 & 53 & 62.4 & 95.13 & $0.000 * *$ & $\mathbf{8 8 . 0 3}$ & $0.000 * *$ \\
\hline $\begin{array}{l}\text { Done } \\
\text { Incompletely }\end{array}$ & $\mathbf{0}$ & $\mathbf{0 . 0}$ & $\mathbf{0}$ & $\mathbf{0 . 0}$ & 5 & 5.9 & & & & \\
\hline Not done & 85 & 100.0 & 24 & 28.2 & 27 & 31.8 & & & & \\
\hline Assess patien & risk & or hypc & hermia & & & & & & & \\
\hline $\begin{array}{l}\text { Done } \\
\text { completely }\end{array}$ & $\mathbf{0}$ & $\mathbf{0 . 0}$ & 61 & 71.8 & 51 & 60.0 & 95.13 & $0.000 * *$ & $0.000 * *$ & 81.30 \\
\hline $\begin{array}{l}\text { Done } \\
\text { Incompletely }\end{array}$ & $\mathbf{0}$ & 0.0 & $\mathbf{0}$ & 0.0 & 4 & 4.7 & & & & \\
\hline Not done & 85 & 100.0 & 24 & 28.2 & 30 & 35.3 & & & & \\
\hline Assess compli & ation & f hypo & hermia & during & surg & & & & & \\
\hline $\begin{array}{l}\text { Done } \\
\text { completely }\end{array}$ & 7 & 8.2 & 61 & 71.8 & 58 & 68.2 & 71.47 & $0.000 * *$ & $0.000 * *$ & 71.60 \\
\hline $\begin{array}{l}\text { Done } \\
\text { Incompletely }\end{array}$ & $\mathbf{0}$ & 0.0 & $\mathbf{0}$ & 0.0 & 3 & 3.5 & & & & \\
\hline Not done & 78 & 91.8 & 24 & 28.2 & 24 & 28.2 & & & & \\
\hline
\end{tabular}

$\mathrm{X}^{2} 1$ between pre and post program

$\mathrm{X}^{2} 2$ between pre and after one month program

*A statistical significant differences $(\mathrm{P} \leq 0.05) \quad * *$ A highly statistically significant differences

$(\mathrm{P} \leq 0.001)$ 
Table (4): Correlation between total knowledge and practices score of studied nurses through the program phases (pre, immediately post, after one month of program)

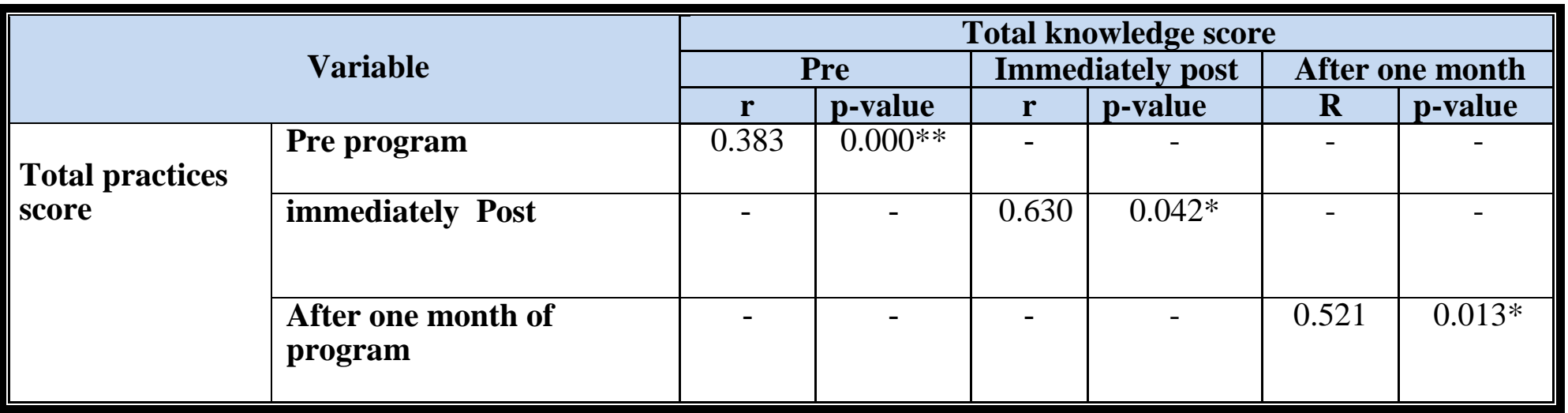

Table 5: Frequency and percentage distribution of studied patients according to their demographic characteristics $(\mathbf{N}=\mathbf{5 0})$

\begin{tabular}{|c|c|c|}
\hline Demographic characteristics & No (50) & Percentage\% \\
\hline \multicolumn{3}{|l|}{ Age in years } \\
\hline$\bullet \quad<30$ & 15 & 30.0 \\
\hline - $30-<40$ & 8 & 16.0 \\
\hline - $40+$ & 27 & 54.0 \\
\hline Min -Max & $23-57$ & - \\
\hline Range & 34 & - \\
\hline \multicolumn{3}{|c|}{ Mean \pm SD $\quad 40.40 \pm 12.196$} \\
\hline \multicolumn{3}{|c|}{ 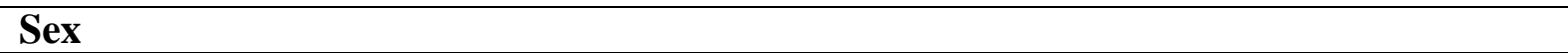 } \\
\hline - Male & 12 & 24.0 \\
\hline - Female & 38 & 76.0 \\
\hline \multicolumn{3}{|l|}{ Marital status } \\
\hline - Single & 10 & 20.0 \\
\hline - $\quad$ Married & 40 & 80.0 \\
\hline \multicolumn{3}{|l|}{ Level of education } \\
\hline - Illiterate & 9 & 18.0 \\
\hline - Primary & 13 & 26.0 \\
\hline - Secondary & 5 & 10.0 \\
\hline - University & 23 & 46.0 \\
\hline \multicolumn{3}{|l|}{ Occupation } \\
\hline - Not work & 18 & 36.0 \\
\hline - Work & 21 & 42.0 \\
\hline - House wife & 11 & 22.0 \\
\hline \multicolumn{3}{|l|}{ Place of residence } \\
\hline - Urban & 32 & 64.0 \\
\hline - $\quad$ Rural & 18 & 36.0 \\
\hline
\end{tabular}


Table (6): Frequency and percentage distribution of studied patients regarding Bates- Jensen assessment score of wound infection through the program phases $(n=50)$

\begin{tabular}{|c|c|c|c|c|c|c|c|c|c|c|}
\hline \multirow{2}{*}{$\begin{array}{l}\text { Bates-Jensen wound } \\
\text { assessment score }\end{array}$} & \multicolumn{2}{|c|}{ reprogram } & \multicolumn{2}{|c|}{ hediately post } & \multicolumn{2}{|c|}{ one month } & & \multicolumn{2}{|l|}{-value } & p-value \\
\hline & No & $\%$ & No & $\%$ & No & $\%$ & \multirow{7}{*}{$\begin{array}{r}1.1 \\
56\end{array}$} & \multirow{7}{*}{$\begin{array}{r}0.5 \\
61\end{array}$} & \multirow{7}{*}{$\begin{array}{r}0.8 \\
45\end{array}$} & \multirow{7}{*}{0.656} \\
\hline -Satisfactory healing & 37 & 74.0 & 43 & 86.0 & 43 & 86.0 & & & & \\
\hline -Disturbance of healing & 7 & 14.0 & 4 & 8.0 & 3 & 6.0 & & & & \\
\hline -Minor wound infection & 5 & 10.0 & 3 & 6.0 & 3 & 6.0 & & & & \\
\hline -Moderate wound infection & 1 & 2.0 & 0 & 0.0 & 1 & 2.0 & & & & \\
\hline -Severe wound infection & 0 & 0.0 & 0 & 0.0 & 0 & 0.0 & & & & \\
\hline Mean \pm SD & $\begin{array}{c}12.5 \\
2\end{array}$ & $\begin{array}{c} \pm 4.3 \\
5\end{array}$ & $\begin{array}{c}17.3 \\
3\end{array}$ & $\begin{array}{c} \pm 3.6 \\
6\end{array}$ & 15.32 & $\begin{array}{c}+5.3 \\
0\end{array}$ & & & & \\
\hline
\end{tabular}

$\mathrm{X}^{2}$ 1between pre and post program

$\mathrm{X}^{2}$ 2between pre and after one month program

Table (7): Correlation between total nurses` practices and wound assessment score through the program phases $n=50$ patients

\begin{tabular}{||c|c|c|c|c|c|c|}
\hline \multirow{2}{*}{ Item } & \multicolumn{5}{|c|}{ Total practices } \\
\cline { 2 - 7 } & \multicolumn{2}{|c|}{ preprogram } & Immediately post & \multicolumn{2}{c|}{ After one month } \\
\hline \multirow{2}{*}{ Wound assessment score } & $\mathbf{r}$ & P-value & $\mathbf{R}$ & P-value & r & P-value \\
\cline { 2 - 7 } & $\mathbf{0 . 0 3 5}$ & $\mathbf{0 . 8 0 9}$ & $\mathbf{0 . 5 2 9}$ & $\mathbf{0 . 0 0 1} * *$ & $\mathbf{0 . 0 4 0}$ & $\mathbf{0 . 7 5 4}$ \\
\hline
\end{tabular}

\section{Discussion:}

To fulfill the aim of this study, the discussion of the finding is presented in the following sections.

\section{Demographic Characteristics of the Studied} Nurses:

Regarding age, the present study revealed that, about slightly less than half of studied nurses were between the ages of 20 to less than 30 years old. From the present study researcher's point of view, this result might be due to the fact that nurses more than 30 years old leave the operating room and transfer to another unit because of the workload of the work in such units, These finding agreed with
Jung et al.(2020), who studied the" Comparison of Nursing Performance Competencies and Practical Education Needs Based on Clinical Careers of Operating Room Nurses " and mentioned that the nurses were aged 20 to less than 30 years old,

As regard to gender, marital status: the present study showed that about three quarter were female and majority of them were married. From the researcher's point of view, This result may be because there is great fraction of the nurse's task force in Egypt was female. Nursing in Egyptian universities were exclusive for females till a few years ago. Theses finding agreed with AORN, (2018), who study the "Guideline for prevention of 
unplanned patient hypothermia" and reported that three quarter were female and the majority of studied nurses were married.

In respect to the level of education: the result of the present study revealed that more than half of the nurses under study were holding clinical nursing technical institute diploma. The investigator believed that, this might be due to that a large number of bedside nurses in governmental hospitals were graduated from the nursing technical institute diploma, because bachelor nurses in the governmental hospitals usually working as head nurses or supervisors, These results are in the same line with a study done by Mendoza\& Peniche, (2012), whose study about" Educational intervention regarding hypothermia: a teaching strategy for education in the Surgery Department, University São Paulo \& Brazil" who mentioned that more than half of the nurses under study were having technical institute diploma.

As regards years of experience, the result showed that the majority of studied nurses ranged between from one year to less than five year of experience. This result may be due to that less than half of nurses under study were younger than 30 years old study revealed that, about three quarter of studied nurses had incorrect answer of knowledge regarding heat loss that occur through the indirect contact with the patient's cold body pre-program implementation, while the majority of them had answered correctly during immediately post program implementation and the highest percentage of them had correct answer after one month of program implementation. From the current study researcher's point of view, this result might be due to that they did not attend any training courses specific to perioperative hypothermia. This finding agreed with a study conducted by Munday et al. ( 2019), who studied that "Barriers and enablers to the implementation of perioperative hypothermia prevention practices from the perspectives of the multidisciplinary team" and
.These finding agreed with ( JALLOW, 2020), who studied the" Nurses' awareness and practice of perioperative hypothermia prevention, master thesis, Near East university\& Madison," and mentioned that The majority of nurses had less than or equal to 5 years working experience.

\section{As regards training courses regarding} perioperative hypothermia: The present result showed that, all of the nurses under study did not attend any training course. This might be due to that the majority of the nurses were female with family commitments, lack of time and workload in the operating room and surgical ward may be also behind the reason. These findings was congruent with a study done by Senol \& Yildiz, (2019), whose study about" Effects of A training Programme on the Awareness of Inadvertent Perioperative Hypothermia among Nurses. Doctorate thesis, Tekirdag Namık Kemal University\& United States" who mentioned the all of studied nurses had no previous training courses regarding perioperative hypothermia.

\section{Regarding nurses` general knowledge regarding perioperative hypothermia, this}

reported that about three quarter of studied nurses had unsatisfactory level of knowledge regarding heat loss that occur through the indirect contact with the patient's cold body.

\section{Concerning level of studied nurses' practice regarding intra operative care about} hypothermia, the present study clarified that, all of studied nurses not done assess patients' sign and symptoms of hypothermia at preprogram implementation, while more than two third of them had complete done immediately post of program implementation, but about two third of studied nurses had complete done after one month of program implementation. From the present study researcher's point of view, it may be because there are lack of training staff in hospital and no opportunity to deliver best practice in surgical 


\section{Effect of Educational Program Regarding Perioperative Hypothermia on Nurses Performance and Abdominal Surgery Patients` Outcomes}

setting. This study agreed with Slagle, (2017), who study the" Implementation of a warming protocol to prevent inadvertent perioperative hypothermia in the surgical setting, master thesis, University of San Francisco" and found that all of studied nurses didn't have satisfactory level of practice regarding assess patients' sign and symptoms of hypothermia. And also concluded that change in nursing practice to best is difficult due to time constraints.

By studying the correlation between participants' total level of knowledge and the total level of practice, this study noted that, there was a highly statistical significant differences with positive correlation between the studied nurses total knowledge and practices level at preprogram implementation $(\mathrm{p} \leq 0.000)$. Moreover, there was a statistical significant differences with positive correlation between total knowledge and practice level immediately post and after one month of program implementation. From the present study researcher's point of view, this may be because that nurses' knowledge increase with more practice and vice versa, this means that when knowledge of nurses increases, it will improve the performance. This result agreed with Pourrezaei et al. (2018), reported that there were statistical significant differences between total knowledge and practice level through program implementation. On other hand this this results agreed with Agresa et al.(2018), whose study about "The Relationship Between The Level Of Nursing Knowledge On Prevention Of Hypothermia Post-Operation Of General Anesthesia" revealed that there were statistical significant differences between total knowledge and practice level.

\section{Clinical patient outcome:}

Regarding age: the present study revealed that more than one half of studied patients`age was 40 years or over mean age. From the present study researcher's point of view, this result may be because advanced age make patient high risk for hypothermia. This result was consistent with the result of Mahmoud et al, (2019), whose study was about "Predictors of Intraoperative Hypothermia among Patients Undergoing Major Abdominal Surgeries, master thesis, Cairo University \& Egypt, and stated that more than half of studied patients age was 40 years or more,

As regard to gender: the present study revealed that three quarter of studied patient were female. From the present study researcher`s point of view, females are more likely to develop hypothermia because women have less muscle mass and higher body surface index, leading to greater heat loss to the environment. This result was supported with the result of Lau et al, (2018), whose study about "Effect of preoperative warming on intraoperative hypothermia, master thesis, University of British Columbia\& Canada", and reported that three quarter of studied patient were female Concerning marital status, the present study finding revealed that the majority of studied patients were married.

This study agreed with Sagiroglu et al, (2020), whose study about "Inadvertent Perioperative Hypothermia and Important Risk Factors during Major Abdominal Surgeries, PhD, Trakya University \&Turkey" reported that the majority of studied patient were married.

Also, this finding inconsistent with Zaman et al, (2018), whose study about" A Clinical Trial of the Effect of Warm Intravenous Fluids on Core Temperature and Shivering in Patients Undergoing Abdominal Surgery, PhD thesis, Rush University\& Chicago". reported that all of studied patients were married.

As regard to residence, the finding of the present study stated that about two third of studied patients were living in urban, similarly, this result was consistent with Abdeltwab et al ., (2017) whose study whose about "Impact of Induced Normothermia on Occurrence of Post Anesthetic Shivering and Wound Infection among Patients 
Undergoing Abdominal Surgeries, master thesis, Cairo University- Egypt", concluded that more than half of studied patients were living in urban

In respect to level of education, the result of the present study revealed that slightly less than half of studied patients had university education. From the present study researcher point of view, because the most of studied patients live in urban area more attention to education and increase the level of health awareness. This finding disagreed with the result of El-Kased et al, (2017), whose study was about" The Effect of Perioperative Warming Measures for Major Abdominal Surgery on Postoperative Hypothermia, PhD thesis, Menoufia University \& Egypt", reported that the minority of studied patients had university education.

Concerning occupation, the current study clarified that, slightly less than half of studied patients were employed, this this study agreed with Denu et al, (2015), whose study was about "Perioperative Hypothermia and Predictors of Intra Operative Hypothermia among Patients Operated at Gondar university Hospital" reported that about one half of studied patients were employed, this could be because most of studied patients were have high education.

Regarding Bates- Jensen assessment wound score, this study revealed that regarding BatesJensen wound assessment score of studied patients, the lowest percentage $(14 \%)$ of studied patients have disturbance of healing preprogram implementation, and lowest percentages $(8 \%, 6 \%)$ respectively immediately post and after one month of program implementation have disturbance of healing. This finding agreed with the study of conducted by Constantine et al, (2015), whose study about "The impact of perioperative hypothermia on abdominal surgery outcomes" who revealed that the minority of studied patients have disturbance of wound healing.
Also, this study mentioned that, about the minority of studied patients pre-program implementation, and the lowest percentages immediately post and after one month of program implementation have wound infection with no statistical significant differences. This study was consistent with Mason et al, (2017), whose study entitled "Postoperative hypothermia and surgical site infection following laparoscopic colorectal surgery. Doctorate thesis, Colchester University\& England", and reported that about the minority of studied patients preprogram implementation, and the lowest percentage of studied patients after program implementation developed surgical site infections with no statistical significant differences and concluded that the relationship between hypothermia and surgical site infections was sufficiently strong.

This study was in consistent with the study of $\mathbf{B u}$ et al, (2019), whose study entitled "Association between perioperative hypothermia and surgical site infection, Doctorate thesis, Jiaotong University\& China", and reported that no association between perioperative hypothermia and the risk of surgical site infections in the surgical patients.

Regarding to the correlation between total nurses` practices and patients 'wound assessment score, it was noted there were positive statistical significant correlation between studied nurses' total practice level and wound assessment score through program phases, with a highly statistical significant immediately post of program implementation. This study agreed Link, (2020), which reported that there were highly statistically significant differences with positive correlation between total nurses' practice and wound assessment score. In addition to Senkal \& Kara, (2020), who revealed that, there were highly statistically significant differences between total nurses practice and wound assessment score post educational implementation. 


\section{Effect of Educational Program Regarding Perioperative Hypothermia on Nurses \\ Performance and Abdominal Surgery Patients` Outcomes}

Conclusion:

The knowledge scores of nurses after implementation of educational program of perioperative hypothermia in post immediate and after one month were higher than pre educational program. Also, it revealed that nurses` practice improves after implementation of educational program in post immediate and after one month. There were highly statistically significant differences in nurses` knowledge and practice regarding perioperative hypothermia between pre and immediately post and between pre and after one month $\left(\mathrm{P} \leq 0.000^{* *}\right)$, this affects positive in patients outcomes. There were statistically significant differences between the studied nurses knowledge and their performance and patients outcomes, this means that the application of the educational program can improve nurses knowledge, enhance their practice, reduce patients length of hospital stay and improve wound healing.

\section{Recommendation:}

- Research is needed for replication of the current study on larger probability sample from different geographical location is recommended to achieve generalization of the result.

- Research is need for ongoing education, training, and evaluation of studied nurses to ensure that they are aware of the details program regarding perioperative hypothermia.

- Research is needed to duplicate the study to determine the effect of educational program on postoperative patients`outcome

\section{References}

Abdeltwab, S. A. Q., Hashem, H. Y., Hassan, A. D. A. F., \& Ahmed, H. O.(2017). Impact of Induced Normothermia on Occurrence of Post Anesthetic Shivering and Wound Infection among Patient. Undergoing Abdominal Surgeries. Journal of Nursing and health Science,
Agresa, N., Rahayu, H., \& Limson, L. (2018). The Relationship Between The Level Of Nursing Knowledge On Prevention Of Hypothermia PostOperation Of General Anesthesia In The St. Vincentius Hospital Year 2017. SCIENTIFIC JOURNAL OF NURSING RESARCH, 1(1), 1521.

AORN, (2018). Guideline for prevention of unplanned patient hypothermia. In: Guidelines for perioperative practice. Denver, CO, Inc :531-554.

Bates-Jensen, B. M., McCreath, H. E., Harputlu, D., \& Patlan, A. (2019). Reliability of the BatesJensen wound assessment tool for pressure injury assessment: The pressure ulcer detection study. Wound Repair and Regeneration, 27(4), 386-395.

Bu, N., Zhao, E., Gao, Y., Zhao, S., Bo, W., Kong, Z., ... \& Gao, W. (2019). Association between perioperative hypothermia and surgical site infection: A meta-analysis. Medicine, 98(6).

Constantine, R. S., Kenkel, M., Hein, R. E., Cortez, R., Anigian, K., Davis, K. E., \& Kenkel, J. M. (2015). The impact of perioperative hypothermia on plastic surgery outcomes: a multivariate logistic regression of 1062 cases. Aesthetic surgery journal, Texas, 35(1), 81-88.

El-Kased, A. F., Shehata, A. E. S., Atalla, H., Amar, M. S., \& Adel, S.(2017). The Effect of Perioperative Warming Measures for Major Abdominal Surgery on Postoperative Hypothermia.

Honkavuo, L., \& Loe, S. A. K. (2020). Nurse Anesthetists' and Operating Theater Nurses' Experiences with Inadvertent Hypothermia in

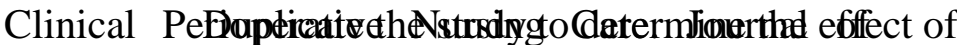
PeriAnesthesia Nursing.

Jung, J. H., Kim, H. J., \& Kim, J. S. (2020, June). Comparison of Nursing Performance Competencies and Practical Education Needs Based on Clinical Careers of Operating Room Nurses: A Cross-Sectional Study. In Healthcare 
(Vol. 8, No. 2, p. 136). Multidisciplinary Digital Publishing Institute.

Kang, S., \& Park, S. (2020). Effect of the ASPAN Guideline on Perioperative Hypothermia Among Patients With Upper Extremity Surgery Under General Anesthesia: A Randomized Controlled Trial. Journal of PeriAnesthesia Nursing.

Lau, A., Lowlaavar, N., Cooke, E. M., West, N., German, A., Morse, D. J., ... \& Merchant, R. N. (2018). Effect of preoperative warming on intraoperative hypothermia: a randomizedcontrolled trial. Canadian Journal of Anesthesia/Journal canadien d'anesthésie, 65(9), 1029-1040.

Link, T. (2020). Guidelines in Practice: Hypothermia Prevention. AORN Journal, Africa,111(6),653-666.

Mahmoud, W. I., Abd El-Naby, A. G., Deif, H. I. A., \& EL-Hadia, H. M.(2019). Predictors of Intraoperative Hypothermia among Patients Undergoing Major Abdominal Surgeries.

Mason, S. E., Kinross, J. M., Hendricks, J., \& Arulampalam, T. H. (2017). Postoperative hypothermia and surgical site infection following peritoneal insufflation with warm, humidified carbon dioxide during laparoscopic colorectal surgery: a cohort study with cost-effectiveness analysis. Surgical endoscopy,England, 31(4), 1923 1929.

Mendoza, I. Y., \& Peniche, C. A. (2012). Educational intervention regarding hypothermia: a teaching strategy for education in the Surgery D

Munday, J., Delaforce, A., Forbes, G., \& Keogh, S. (2019). Barriers and enablers to the implementation of perioperative hypothermia prevention practices from the perspectives of the multidisciplinary team: a qualitative study using the Theoretical Domains Framework. Journal of Multidisciplinary Healthcare, 12, 395.
Pourrezaei, S., Dinmohammadi, M., \& Jafarirouhi, A. (2018). The Effect of Thermal Care Workshop on Nursing Staff Readiness in managing Hypothermia in Surgical Patients. Preventive Care in Nursing and Midwifery Journal, 8(2), 26-33.

Reeve, J. L., \& Herring, J. P. (2017). Conductive skin warming and hypothermia: An observational study. AANA journal, 85(6), 461-468.

Sagiroglu, G., Ozturk, G. A., Baysal, A., \& Turan, F. N. (2020). Inadvertent Perioperative Hypothermia and Important Risk Factors during Major Abdominal Surgeries. Journal of the College of Physicians and Surgeons Pakistan, 30(2), 123128.

Şenkal, S., \& Kara, U. (2020). Guideline implementation and raising awareness for unintended perioperative hypothermia: Singlegroup "before and after" study. Ulus Travma Acil Cerrahi Derg, 26(5), 719-727.

Senol, T., \& Yildiz, T.(2019). Effects of A training Programme on the Awareness of Inadvertent Perioperative Hypothermia among Nurses. Current Health Studies, 27.

Slagle, J. A. (2017). Implementation of a warming protocol to prevent inadvertent perioperative hypothermia in the surgical setting. Master's Projects and Capstones. 161. https://repository.usfca.edu/capstone/161

Zaman, S. S., Rahmani, F., Majedi, M. A., Roshani, D., \& Valiee, S. (2018). A Clinical Trial of the Effect of Warm Intravenous Fluids on Core Temperature and Shivering in Patients Undergoing Abdominal Surgery. Journal of PeriAnesthesia Nursing, 33(5), 616-625. 
تأثير البرنامج التطليمي فيما يتعلق بانخفاض درجة حرارة الجسم أثثاء مراحل العملية الجراحية علي أداء الممرضات ومخرجات مرضي جراحة البطن

نجلاء فتحي محمود الطويل ـأمل سعيد طهـ صفاء عحم حامد

انخفاض درجة حرارة الجسم أثناء مر احل العملية الجر احية هي أحد المضاعفات الثائعة للإجر اءات

المحيطة بالجر احة، وقد تكون شائعة بين المرضي الذين يخضعون للعمليات الجر احية ،وقد تسبب إنخفاض هُ درجة حرارة الجسم مضاعفات خطيرة بالنسبة للمرضي منها خطر النزيف الجراحي، زيادة فترة اقامة المريض بالمستشفي ،وزيادة معدلات الإصابة للعدوى في مكان الجرح بعد العملية الجر احية .لذلك هدفت هذه الدراسة الي تقييم تأثير البرنامج التعليمي فيما يتعلق بانخفاض درجة حرارة الجسم أثناء مراحل العملية الجر احية علي أداء الممرضات ومخرجات مرضي جر احة البطن، وقد أجريت هذه الدراسة بقسم العمليات الجراحية وقسم جر احة حريم ورجال بمستشفي جامعة بنها وتم تحديد 10 ممرض وممرضة بالعمليات

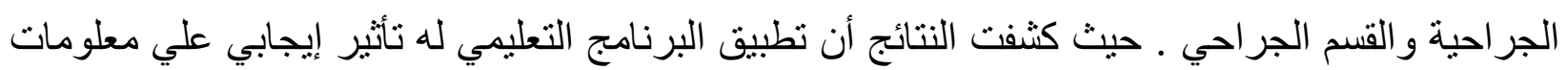
و أداء المررضات عن كيفية تقديم العناية التمريضية للمرضى الذين يعانون من انخفاض درجة الحرارة أثناء مراحل العطلية الجراحية المختلفة لتحسين نتائج المرضي الخاضعين للعمليات الجراحية ، كما أوصت الدراسة للتعليم المستمر والتدريب وتقييم التمريض الخاضعين للاراسة والقيام بدورات تدريبية مخصصة للتمريض لتحسين المعلومات والمهارات المتعلقة بانخفاض درجة حرارة الجسم أثناء مراحل العملية الجراحية المختلفة كما أوصت أيضا بتوفير كتيب مبسط وشامل لجميع الممرضات بالعمليات الجراحية و القسم الجر احي و الذي يتضمن شرحا واضحا ومختصر ا وبسيطا عن كيفية تقديم العناية التمريضية للمرضي الذين يعانون من انخفاض درجة حرارة الجسم أثناء مر احل العملية الجر احية الدختلفة . 